\title{
Long Term Crop-Livestock Managements on Physical Soil Attributes and Total Organic Carbon
}

\author{
Edivan José Possamai \\ Institute of Development Rural of Paraná - IAPAR-EMATER, Brazil \\ Paulo Cesar Conceição \\ UTFPR, Brazil \\ Lizete Stumpf \\ UFPEL, Brazil
}

Cristiane Dalagua Paier, Jaqueline Kristiane da Rosa, Paulo Fernando Adami

UTFPR, Brazil

Received: Oct. 8, 2020

Accepted: Nov. 9, 2020

Published: Nov. 19, 2020

doi:10.5296/jas.v9i1.17781

URL: https://doi.org/10.5296/jas.v9i1.17781

\begin{abstract}
Crop-livestock system (CLS) based on summer crops, as soybean and corn, in rotation with oat+ryegrass pasture in winter for dairy products, is the most adopted productive system at the southern region of Paraná, Brazil. Although its management needs to be evaluated, in order to improve its sustainability. In this sense, this study aimed to measure the impacts of management practices of five smallholder farms on soil quality, considering the soil use history. Soil samples were collected to determine soil bulk density (BD), macroporosity (Ma), microporosity (Mi), weighted mean diameter (WMD) in each area under CLS, summer pasture and native forest, as a control. Areas under CLS altered soil physical attributes (higher BD and Mi and lower Ma) in relation to the non-anthropized area as a consequence of animal trampling. However, the conservationist management adopted, with the soil cover maintenance along with years of minimum tillage, the use of grasses with aggressive roots along with the winter period, did not culminate in limitations of soil functions. Soil structure dynamics needs to be investigated to better determine the biological and physical influence
\end{abstract}


on the formation of soil aggregation.

Keywords: bulk density, macroporosity, aggregation, grasses

\section{Introduction}

In Paraná state, Brazil, it has more than one hundred thousand farms working with crop-livestock system (CLS). At its southwest region, $88 \%$ of these smallholders has between 20 and 30 hectares, and duties are being taken care by those families (IBGE, 2006). In this system, farmers mainly grow soybean and corn for silage, or grains in summer in rotation with oats/ryegrass for graze in winter (Perin et al., 2001). According to Balbinot Junior et al. (2009a) and Cordeiro et al. (2017) the CLS enables a better use of the farm productive structure and its land, as well as minimizes climatic and market risks, diversifying farmers' sources of income with better use of family labor. Thus, the adoption of CLS may increase the utilization of the production's factors and the environmental supply of the agricultural areas, ranging from $90 \%$ and $100 \%$ of the time, making it an efficient strategy for a sustainable intensification of land use in tropical regions (Cordeiro et al., 2017).

In general, soils under CLS present the maintenance or increase of the chemical (Ferreira et al., 2009; Anghinoni et al., 2011), physical (Salton et al., 2008; Souza et al., 2009; Conte et al., 2011) and biological (Souza et al., 2009; Silva et al., 2011; Carvalho et al., 2016) quality. On the other hand, on farms where it is overgrazed, there is a negative effect in summer crops yield, promoted by higher stocking rates (Assman and Pin, 2008). Consequently, bulk density increase and soil surface sealing may occur due to animal trampling (Flores et al., 2007; Anghinoni et al., 2011).

Among the CLS soil quality indicators used to evidence if the system has been managed correctly are: soil bulk density, porosity, aggregation and soil organic carbon content (Spera et al., 2009; Anghinoni et al., 2011; Carvalho et al., 2016).

In this context, amid the rural extension and technical assistance projects in Paraná state, the "Reference Networks for Family Agriculture" program developed by Institute of Development Rural of Paraná - IAPAR-EMATER stands out, in which aims to implement actions to improve production systems and generate reference farms (Perin et al., 2001; $\mathrm{SEAB}, 2010)$. In the southwest region of Paraná, the work started in 1998 by the program pointed by CLS, as potential activity in several agricultural establishments. In this context, the objective of the study was to evaluate the physical attributes and total organic carbon of the areas under CLS, SP and NF of five smallholder's farms which represent the great reality in the southwest of Paraná-Brazil, aiming to measure the impacts of its management on soil quality.

\section{Method}

This work was carried out in five smallholder's farms in the southwest region of Paraná, Brazil, distributed in the cities of Honório Serpa, Saudade do Iguaçu, Vitorino, Pato Branco and Ampére. All the evaluated farms are collaborators of the Reference Networks for Family Agriculture program, who have received crop-livestock management support practices since 
1998. Table 1 shows soil management history adopted along three years, in each of the evaluated agricultural areas, where soil NT: no-tillage; CT: conventional tillage; MT: minimum tillage management were adopted, and Table 2 shows the soil class, area size, predominant granulometry and the main soil chemical attributes in the $0.00-0.20 \mathrm{~m}$ layer. In each farm, soil quality under CLS, summer pasture (SP - grass cultivar Tifton 85) and native forest nearby (NF) was evaluated.

Along September and October, coinciding with the end of the winter pasture cycle and preceding the sowing of summer species, soil samples were collected to determine the soil bulk density (BD), macroporosity (Ma), microporosity (Mi) weighted mean diameter (WMD) in each area under CLS, SP and NF. Undisturbed samples (135) were collected in the $0.00-0.05,0.05-0.10$ and $0.10-0.20 \mathrm{~m}$ layers (three managements $\times$ three replicates per management $\times$ three soil layers $\times$ five farms) with stainless steel cylinders $\left(85 \mathrm{~cm}^{3}\right)$ for determination of BD, Ma, Mi and total porosity (Pt), according to Donagema et al. (2011). The samples were saturated in water for 24 hours, weighed, placed on a tension table at a pressure of $0.6 \mathrm{mca}$, for 72 hours, so the water retained in the macropores could be drained (pores greater than $50 \mu \mathrm{m}$ ) and weighed. The samples were taken to the oven at $105^{\circ} \mathrm{C}$ for 24 hours for total water drainage. The BD values were obtained by the ratio between the dry soil mass and the volume of the sample cylinder. Pt was obtained by the difference between the mass of saturated soil and the mass of dry soil. Mi was obtained due to the difference between the stressed soil mass of 0.6 mca and the dry soil mass, and Ma was obtained due to the difference between $\mathrm{Pt}$ and Mi. The values were expressed as a percentage of porous volume in relation to the total volume of the sample, by the ratio of mass and volume of water. Through the equation BDcRest $=1.86-0.00071$ clay, Reichert et al. (2009), the soil bulk density restrictive for root growth (BDrest) in the 0.00-0.20 m layer under agricultural areas (CLS and SP) was estimated.

Table 1. Land use history and soil management in areas under crop livestock system (CLS) and summer pasture (SP) on five smallholders' farms in the southwest of Paraná, Brazil

\begin{tabular}{|c|c|c|c|c|c|c|c|c|c|c|c|}
\hline \multirow{2}{*}{$\begin{array}{l}\text { Farm's } \\
\text { City }\end{array}$} & \multirow{2}{*}{ Management } & \multicolumn{2}{|c|}{-------First Year ------- } & \multicolumn{2}{|c|}{------Second Year ------- } & \multicolumn{2}{|c|}{------ Third Year ------- } & \multirow{2}{*}{$\begin{array}{r}\mathbf{N} \\
\mathbf{K} \\
\end{array}$} & \multirow{2}{*}{$\begin{array}{c}\mathrm{P}_{2} \mathrm{O}_{5} \\
\mathrm{Kg} \mathrm{ha}^{-1 * *} \\
\end{array}$} & \multirow{2}{*}{$\begin{array}{r}\mathbf{K}_{2} \mathbf{O} \\
* \\
\end{array}$} & \multirow{2}{*}{$\begin{array}{c}\text { Stocking } \\
\text { rate } \\
\mathrm{kg} \mathrm{Pv} \mathbf{P v} \\
\mathrm{ha}^{-1 * * * * *}\end{array}$} \\
\hline & & Summer & Winter & Summer & Winter & Summer & Winter & & & & \\
\hline \multirow{2}{*}{ Honório Serpa } & CLS & $\begin{array}{l}\text { Soybean } \\
\text { (NT) }\end{array}$ & $\begin{array}{c}\text { Oats + } \\
\text { ryegrass } \\
(\mathrm{CM})\end{array}$ & $\begin{array}{l}\text { Corn silage } \\
\text { (NT) }\end{array}$ & $\begin{array}{c}\text { Oats + } \\
\text { ryegrass } \\
(\mathrm{CM})\end{array}$ & $\begin{array}{l}\text { Soybean } \\
\text { (NT) }\end{array}$ & $\begin{array}{l}\text { Oats + } \\
\text { ryegrass } \\
(\mathrm{NT})\end{array}$ & 233 & 225 & 225 & 345 \\
\hline & $\mathrm{SP}^{*}$ & $\begin{array}{l}\text { Coast-cross } \\
\text { (CT) }\end{array}$ & $\begin{array}{c}\text { Without } \\
\text { crop } \\
(\mathrm{NM})\end{array}$ & $\begin{array}{l}\text { Coast-cross } \\
\text { (NM) }\end{array}$ & $\begin{array}{c}\text { Oats + } \\
\text { ryegrass } \\
(\mathrm{NM})\end{array}$ & $\begin{array}{l}\text { Coast-cross } \\
\text { (NM) }\end{array}$ & $\begin{array}{c}\text { Oats + } \\
\text { ryegrass } \\
(\mathrm{NM})\end{array}$ & 223 & 93 & 152 & 3520 \\
\hline \multirow[t]{2}{*}{ Saudade do Iguaçu } & CLS** & $\begin{array}{l}\text { Corn silage } \\
\text { (NT) }\end{array}$ & $\begin{array}{c}\text { Oats + } \\
\text { ryegrass } \\
(\mathrm{CM})\end{array}$ & $\begin{array}{l}\text { Corn silage } \\
\text { (NT) }\end{array}$ & $\begin{array}{c}\text { Oats + } \\
\text { ryegrass } \\
\text { (MT) }\end{array}$ & $\begin{array}{c}\text { Soybean } \\
(\mathrm{NT})\end{array}$ & $\begin{array}{c}\text { Oats }+ \\
\text { ryegrass } \\
(\mathrm{MT})\end{array}$ & 1978 & 1862 & 1617 & 1176 \\
\hline & $\mathrm{SP}^{*}$ & $\begin{array}{c}\text { Tifton } 85 \\
(\mathrm{NM})\end{array}$ & $\begin{array}{l}\text { Oats } \\
(\mathrm{NM})\end{array}$ & $\begin{array}{c}\text { Tifton } 85 \\
(\mathrm{NM})\end{array}$ & $\begin{array}{l}\text { Oats } \\
(\mathrm{NM})\end{array}$ & $\begin{array}{c}\text { Tifton } 85 \\
(\mathrm{NM})\end{array}$ & $\begin{array}{l}\text { Oats } \\
(\mathrm{NM})\end{array}$ & 1710 & 1800 & 1575 & 4053 \\
\hline \multirow[t]{2}{*}{ Vitorino } & CLS & $\begin{array}{c}\text { Soybean } \\
\text { (NT) }\end{array}$ & $\begin{array}{l}\text { Ryegrass } \\
\text { (NM) }\end{array}$ & $\begin{array}{l}\text { Soybean } \\
\text { (NT) }\end{array}$ & $\begin{array}{c}\text { Ryegrass } \\
\text { (NM) }\end{array}$ & $\begin{array}{l}\text { Corn silage } \\
\text { (NT) / Bean } \\
\text { (CT) }\end{array}$ & $\begin{array}{l}\text { Oats + } \\
\text { ryegrass } \\
(\mathrm{MT})\end{array}$ & 192 & 262 & 262 & 733 \\
\hline & SP* & $\begin{array}{c}\text { Soybean } \\
(\mathrm{NT})\end{array}$ & $\begin{array}{c}\text { Ryegrass } \\
\text { (NM) }\end{array}$ & $\begin{array}{c}\text { Soybean } \\
\text { (PD) }\end{array}$ & $\begin{array}{c}\text { Ryegrass } \\
\text { (NM) }\end{array}$ & $\begin{array}{c}\text { Coast-cross } \\
(\mathrm{CT})\end{array}$ & $\begin{array}{c}\text { Pousio } \\
(\mathrm{NM})\end{array}$ & 156 & 190 & 190 & 5500 \\
\hline \multirow{2}{*}{ Pato Branco } & CLS & $\begin{array}{l}\text { Corn silage } \\
\text { (NT) }\end{array}$ & $\begin{array}{l}\text { Oats + } \\
\text { ryegrass } \\
\text { (NT) }\end{array}$ & $\begin{array}{l}\text { Bean }(\mathrm{CT}) / \\
\text { Bean }(\mathrm{CT})\end{array}$ & $\begin{array}{c}\text { Oats }+ \\
\text { ryegrass } \\
\text { (NT) }\end{array}$ & $\begin{array}{c}\text { Soybean } \\
\text { (NT) }\end{array}$ & $\begin{array}{l}\text { Oats + } \\
\text { ryegrass } \\
(\mathrm{NT})\end{array}$ & 416 & 385 & 385 & 1000 \\
\hline & SP & $\begin{array}{l}\text { Millet+sorghum } \\
\text { (CT) }\end{array}$ & $\begin{array}{l}\text { Oats + } \\
\text { ryegrass } \\
(\mathrm{NT})\end{array}$ & $\begin{array}{l}\text { Millet+sorghum } \\
\text { (NT) }\end{array}$ & $\begin{array}{c}\text { Oats + } \\
\text { ryegrass } \\
(\mathrm{CT})\end{array}$ & $\begin{array}{l}\text { Millet+sorghum } \\
\text { (NT) }\end{array}$ & $\begin{array}{l}\text { Oats + } \\
\text { ryegrass } \\
(\mathrm{NT})\end{array}$ & 438 & 476 & 252 & 2740 \\
\hline
\end{tabular}




\begin{tabular}{|c|c|c|c|c|c|c|c|c|c|c|c|}
\hline \multirow[t]{2}{*}{ Ampére } & CLS** & $\begin{array}{l}\text { Corn silage } \\
\text { (NT) }\end{array}$ & $\begin{array}{l}\text { Oats } \\
(\mathrm{CM})\end{array}$ & $\begin{array}{l}\text { Corn silage (NT) } \\
\text { / Corn silage } \\
(\mathrm{NT})\end{array}$ & $\begin{array}{l}\text { Ryegrass } \\
\text { (MT) }\end{array}$ & $\begin{array}{l}\text { Corn silage } \\
\text { (NT) / Soybean } \\
\text { (NT) }\end{array}$ & $\begin{array}{l}\text { Oats } \\
\text { (MT) }\end{array}$ & 1465 & 1040 & 816 & 1856 \\
\hline & SP* & $\begin{array}{l}\text { Tifton } 85 \\
(\mathrm{NM})\end{array}$ & $\begin{array}{l}\text { Fallow } \\
(\mathrm{SM})\end{array}$ & $\begin{array}{l}\text { Tifton } 85 \\
(\mathrm{NM})\end{array}$ & $\begin{array}{r}\text { Fallow } \\
(\mathrm{NM})\end{array}$ & $\begin{array}{l}\text { Tifton } 85 \\
(\mathrm{NM})\end{array}$ & $\begin{array}{l}\text { Fallow } \\
(\mathrm{NM})\end{array}$ & 749 & 123 & 75 & 2970 \\
\hline
\end{tabular}

*: night stocking of animals throughout the year; **: Use of poultry litter; NT: no-tillage; CT: conventional tillage; MT: minimum tillage; NM: no management (seeding without tillage); +: plant consortium; /: plant sequential; ***: total $\mathrm{N}, \mathrm{P}_{2} \mathrm{O}_{5}$ and $\mathrm{K}_{2} \mathrm{O}$ amount used in three years; ****: Livestock weight amount estimated of grazing cattle divided by total grazed area during winter for CLS and summer for SP in the $3^{\text {rd }}$ evaluated year.

Table 2. Farms size and soil traits as soil class, predominant granulometric fraction, $\mathrm{pH}$, base saturation $(\mathrm{V})$, aluminum saturation $(\mathrm{m})$, phosphorus content $(\mathrm{P})$ under crop-livestock system (CLS), and summer pasture (SP) at five smallholder's farms in the southwest of Paraná, Brazil

\begin{tabular}{|c|c|c|c|c|c|c|c|c|}
\hline \multirow{2}{*}{$\begin{array}{l}\text { Farm's } \\
\text { Locality }\end{array}$} & \multicolumn{2}{|l|}{ Area } & \multirow[b]{2}{*}{ Soil Class } & \multirow{2}{*}{$\begin{array}{l}\text { Clay* } \\
\text { g kg }^{-1}\end{array}$} & \multirow{2}{*}{$\begin{array}{c}\mathbf{p H}^{*} \\
\mathrm{CaCl}_{2}\end{array}$} & \multirow{2}{*}{\multicolumn{2}{|c|}{$\begin{array}{cc}\mathbf{V}^{*} & \mathbf{m}^{*} \\
- & \end{array}$}} & \multirow{2}{*}{$\begin{array}{c}\mathbf{P}^{*} \\
\mathbf{m g} \\
\mathbf{d m}^{-3}\end{array}$} \\
\hline & Management & ha & & & & & & \\
\hline Honório & CLS & 15.3 & \multirow{2}{*}{ Regosols } & \multirow{2}{*}{708} & 5.5 & 74 & 0 & 2.4 \\
\hline Serpa & SP & 1.5 & & & 5.3 & 71 & 0 & 9.0 \\
\hline Saudade do & CLS & 36.2 & \multirow{2}{*}{ Regosols } & \multirow{2}{*}{658} & 5.3 & 67 & 1 & 21.8 \\
\hline Iguaçu & SP & 10.5 & & & 4.8 & 57 & 3 & 23.0 \\
\hline \multirow{2}{*}{ Vitorino } & CLS & 15.0 & \multirow{2}{*}{ Cambisol } & \multirow{2}{*}{625} & 5.9 & 75 & 0 & 7.9 \\
\hline & SP & 2.0 & & & 5.3 & 69 & 0 & 4.8 \\
\hline Pato & CLS & 20.0 & \multirow{2}{*}{ Oxisol } & \multirow{2}{*}{784} & 4.6 & 46 & 6 & 12.5 \\
\hline Branco & SP & 7.3 & & & 4.3 & 37 & 19 & 5.9 \\
\hline \multirow{2}{*}{ Ampere } & CLS & 8.0 & \multirow{2}{*}{ Nitosol } & \multirow{2}{*}{706} & 4.7 & 61 & 2 & 38.7 \\
\hline & SP & 5.0 & & & 5.1 & 68 & 0 & 4.2 \\
\hline
\end{tabular}

*: mean in the $0.00-0.20$ m layer.

Disturbed samples (135) were collected in the 0.00-0.05, 0.05-0.10 and 0.10-0.20 m layers (three managements $\times$ three replicates per management $\times$ three soil layers $\times$ five farms) for determination of the mean weight diameter of water-stable aggregates (MWD) according to Carpenedo and Mielniczuk (1990). In addition, the total organic carbon (TOC) was determined by the Walkley-Black combustion method according to Tedesco et al. (1995).

Soil physical attributes data were compared between CLS, SP and NF areas in each farm, due to the heterogeneity of natural conditions and management among the localities. Data were subjected to analysis of variance by the $\mathrm{F}$ test at a significance level of $5 \%$. When the treatment effect was significant, means were compared by the Tukey test $(\mathrm{p}<0.05)$, performed by Assistat 7.6 beta program.

\section{Results and Discussion}

In general, in the farms, CLS and SP areas showed higher BD and Mi in all soil layers and lower Ma than NF areas (Table 3). This was an expected result because in natural ecosystems, 
the soil reflects a steady state between climate, vegetation, topography and inherent soil characteristics, which provide a continuous organic carbon contribution, organisms abundance and diversity, and a structural condition without animal stocking rate history. However, this steady state is altered when the soil is used for agricultural purposes (Braida and Reichert, 2014), once the entry and exit of carbon is greatly influenced by tillage, species used, crop rotations, fertilization and, mainly, by crop residues management (Campos et al., 2011).

Table 3. Mean values of bulk density, macroporosity, microporosity, weighted mean diameter of water-stable aggregates and total organic carbon in the 0.00-0.05, 0.05-0.10 and 0.10-0.20 $\mathrm{m}$ soil layers under crop-livestock system (CLS) summer pasture (SP) and native forest (NF) on five smallholder's farms in the southwest of Paraná, Brazil

\begin{tabular}{|c|c|c|c|c|c|c|c|c|c|}
\hline \multirow{2}{*}{$\begin{array}{l}\text { Farm's } \\
\text { Locality }\end{array}$} & \multicolumn{2}{|c|}{------ 0.00-0.05 m --------- } & \multirow[b]{2}{*}{ NF } & \multicolumn{3}{|c|}{ 0.05-0.10 m - - } & \multicolumn{3}{|c|}{ - 0.10-0.20 m - - } \\
\hline & CLS & SP & & CLS & SP & NF & CLS & SP & NF \\
\hline & \multicolumn{9}{|c|}{ - } \\
\hline H. Serpa & $1.13 \mathrm{~b}$ & $1.23 \mathrm{a}$ & $0.64 \mathrm{c}$ & $1.08 \mathrm{ab}$ & $1.16 \mathrm{a}$ & $0.82 \mathrm{~b}$ & $1.02 \mathrm{a}$ & $1.11 \mathrm{a}$ & $0.92 \mathrm{a}$ \\
\hline S. do Iguaçu & $1.21 \mathrm{a}$ & $1.20 \mathrm{a}$ & $0.66 \mathrm{~b}$ & $1.18 \mathrm{a}$ & $1.15 \mathrm{a}$ & $0.74 \mathrm{~b}$ & $1.14 \mathrm{a}$ & $1.07 \mathrm{a}$ & $0.85 \mathrm{~b}$ \\
\hline Vitorino & $1.11 \mathrm{a}$ & $1.22 \mathrm{a}$ & $0.64 \mathrm{~b}$ & $1.15 \mathrm{a}$ & $1.17 \mathrm{a}$ & $0.75 \mathrm{~b}$ & $1.10 \mathrm{a}$ & $1.07 \mathrm{a}$ & $0.74 \mathrm{~b}$ \\
\hline Pato Branco & $1.14 \mathrm{a}$ & $1.17 \mathrm{a}$ & $0.64 \mathrm{~b}$ & $1.07 \mathrm{a}$ & $1.16 \mathrm{a}$ & $0.68 \mathrm{~b}$ & $1.03 \mathrm{a}$ & $1.11 \mathrm{a}$ & $0.70 \mathrm{~b}$ \\
\hline Ampére & $1.25 \mathrm{a}$ & $1.23 \mathrm{a}$ & $0.78 \mathrm{~b}$ & $1.24 \mathrm{a}$ & $1.24 \mathrm{a}$ & $0.85 \mathrm{~b}$ & $1.23 \mathrm{a}$ & $1.22 \mathrm{a}$ & $0.89 \mathrm{~b}$ \\
\hline \multirow[t]{2}{*}{ Mean } & 1.17 & 1.21 & 0.67 & 1.14 & 1.18 & 0.77 & 1.10 & 1.12 & 0.82 \\
\hline & \multicolumn{9}{|c|}{ - Macroporosity (\%) } \\
\hline H. Serpa & $12 \mathrm{~b}$ & $10 \mathrm{~b}$ & $33 \mathrm{a}$ & $14 \mathrm{~b}$ & $12 \mathrm{~b}$ & $27 \mathrm{a}$ & $16 \mathrm{a}$ & $15.9 \mathrm{a}$ & $24 \mathrm{a}$ \\
\hline S. do Iguaçu & $19 \mathrm{~b}$ & $12 \mathrm{~b}$ & $38 \mathrm{a}$ & $15 \mathrm{~b}$ & $16 \mathrm{~b}$ & $38 \mathrm{a}$ & $17 \mathrm{~b}$ & $17.8 \mathrm{~b}$ & $36 a$ \\
\hline Vitorino & $17 \mathrm{~b}$ & $8 \mathrm{c}$ & $37 \mathrm{a}$ & $14 \mathrm{~b}$ & $11 \mathrm{~b}$ & $32 \mathrm{a}$ & $16 \mathrm{~b}$ & $17.4 \mathrm{~b}$ & $32 \mathrm{a}$ \\
\hline Pato Branco & $13 \mathrm{~b}$ & $13 \mathrm{~b}$ & $35 \mathrm{a}$ & $18 \mathrm{~b}$ & $15 \mathrm{~b}$ & $38 \mathrm{a}$ & $20 \mathrm{~b}$ & $19.6 \mathrm{~b}$ & $36 a$ \\
\hline Ampére & $10 \mathrm{~b}$ & $11 \mathrm{~b}$ & $39 a$ & $12 \mathrm{~b}$ & $13 \mathrm{~b}$ & $31 \mathrm{a}$ & $11 \mathrm{~b}$ & $14.1 \mathrm{~b}$ & $33 \mathrm{a}$ \\
\hline \multirow[t]{2}{*}{ Mean } & 14 & 11 & 36 & 15 & 14 & 33 & 16 & 16.7 & 32 \\
\hline & \multicolumn{9}{|c|}{ - Microporosity (\%) - } \\
\hline H. Serpa & $45 \mathrm{a}$ & $44 \mathrm{a}$ & $37 \mathrm{a}$ & $45 \mathrm{a}$ & $44 \mathrm{ab}$ & $39 \mathrm{~b}$ & $45 \mathrm{a}$ & $42 \mathrm{a}$ & $41 \mathrm{a}$ \\
\hline S. do Iguaçu & $43 \mathrm{a}$ & $46 \mathrm{a}$ & $31 \mathrm{~b}$ & $45 \mathrm{a}$ & $43 \mathrm{a}$ & $34 \mathrm{~b}$ & $43 \mathrm{a}$ & $42 \mathrm{a}$ & $33 \mathrm{~b}$ \\
\hline Vitorino & $44 \mathrm{ab}$ & $48 \mathrm{a}$ & $35 \mathrm{~b}$ & $46 \mathrm{a}$ & $46 a$ & $34 \mathrm{~b}$ & $43 \mathrm{a}$ & $43 \mathrm{a}$ & $33 \mathrm{~b}$ \\
\hline Pato Branco & $46 \mathrm{a}$ & $46 \mathrm{a}$ & $36 \mathrm{~b}$ & $44 \mathrm{a}$ & $43 \mathrm{a}$ & $36 \mathrm{~b}$ & $42 \mathrm{a}$ & $43 \mathrm{a}$ & $36 \mathrm{a}$ \\
\hline Ampére & $46 \mathrm{a}$ & $47 \mathrm{a}$ & $36 \mathrm{~b}$ & $45 \mathrm{a}$ & $44 \mathrm{a}$ & $38 \mathrm{a}$ & $44 \mathrm{a}$ & $45 \mathrm{a}$ & $37 \mathrm{~b}$ \\
\hline \multirow[t]{2}{*}{ Mean } & 45 & 46 & 35 & 45 & 44 & 36 & 43 & 43 & 36 \\
\hline & \multicolumn{9}{|c|}{ 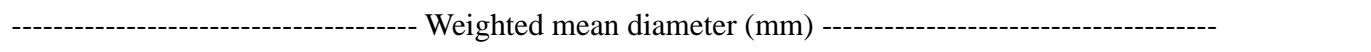 } \\
\hline H. Serpa & $3.90 \mathrm{a}$ & $4.83 \mathrm{a}$ & $2.53 \mathrm{~b}$ & $3.05 \mathrm{ab}$ & $4.17 \mathrm{a}$ & $2.56 \mathrm{~b}$ & $2.69 \mathrm{~b}$ & $3.93 \mathrm{a}$ & $2.60 \mathrm{~b}$ \\
\hline S. do Iguaçu & $3.61 \mathrm{a}$ & $4.45 \mathrm{a}$ & $3.27 \mathrm{a}$ & $3.60 \mathrm{a}$ & $3.65 \mathrm{a}$ & $3.03 \mathrm{a}$ & $2.51 \mathrm{a}$ & $2.64 \mathrm{a}$ & $2.82 \mathrm{a}$ \\
\hline Vitorino & $2.99 \mathrm{a}$ & $3.97 \mathrm{a}$ & $2.67 \mathrm{a}$ & $3.36 \mathrm{a}$ & $3.42 \mathrm{a}$ & $3.18 \mathrm{a}$ & $3.14 \mathrm{a}$ & $3.18 \mathrm{a}$ & $2.88 \mathrm{a}$ \\
\hline Pato Branco & $3.97 \mathrm{~b}$ & $5.06 \mathrm{a}$ & $3.57 \mathrm{c}$ & $3.64 \mathrm{a}$ & $4.27 \mathrm{a}$ & $3.69 \mathrm{a}$ & $3.22 \mathrm{a}$ & $3.46 \mathrm{a}$ & $3.41 \mathrm{a}$ \\
\hline Ampére & $2.94 \mathrm{ab}$ & $3.88 \mathrm{a}$ & $2.47 \mathrm{~b}$ & $2.93 \mathrm{a}$ & $3.06 \mathrm{a}$ & $2.24 \mathrm{a}$ & $2.65 \mathrm{a}$ & $2.72 \mathrm{a}$ & $2.40 \mathrm{a}$ \\
\hline \multirow[t]{2}{*}{ Mean } & 3.48 & 4.44 & 2.90 & 3.32 & 3.71 & 2.94 & 2.84 & 3.19 & 2.82 \\
\hline & \multicolumn{9}{|c|}{ Total organic carbon $\left(\mathrm{g} \mathrm{kg}^{-1}\right)$} \\
\hline H. Serpa & $39.0(-23)^{*}$ & $42.9(-15)$ & 50.7 & $33.5(-4)$ & $28.1(-20)$ & 35.1 & $\begin{array}{c}23.4 \\
(-22)\end{array}$ & $28.1(-5)$ & 29.6 \\
\hline S. do Iguaçu & $35.1(-27)$ & $29.6(-39)$ & 48.3 & $\begin{array}{l}28.8 \\
(-18)\end{array}$ & $\begin{array}{r}21.8 \\
(-38)\end{array}$ & 35.1 & $19.5(-38)$ & $\begin{array}{l}15.6 \\
(-50)\end{array}$ & 31.2 \\
\hline \multirow{2}{*}{ Vitorino } & & & & 19.5 & 24.2 & & & 21.0 & \\
\hline & $31.2(-20)$ & $23.4(-40)$ & 39.0 & $(-37)$ & $(-22)$ & 31.0 & $15.6(-33)$ & $(-10)$ & 23.4 \\
\hline \multirow{2}{*}{ Pato Branco } & & & & 27.3 & 15.6 & & & 23.4 & \\
\hline & $31.2(-26)$ & $29.6(-30)$ & 42.1 & $(-17)$ & $(-52)$ & 32.7 & $27.3(-8)$ & $(-21)$ & 29.6 \\
\hline \multirow{2}{*}{ Ampére } & & & & 23.4 & 19.5 & & & 18.0 & \\
\hline & $23.4(-40)$ & $32.7(-16)$ & 39.0 & $(-25)$ & $(-38)$ & 31.2 & $17.9(-36)$ & $(-36)$ & 28.1 \\
\hline Mean & 32.0 & 31.6 & 43.8 & 26.5 & 21.8 & 33.0 & 20.7 & 21.2 & 29.6 \\
\hline
\end{tabular}




\section{Ml Macrothink}

Means followed by the same letter in the line, within the same locality and the same depth, do not differ by the Tukey test at 5\% probability. *: differences between the values from agricultural management and the native forest $(\%)$.

In this context, soils under CLS and SP, regardless of the farm, generally had a higher BD value and a lower Ma volume in the 0.00-0.05 m layer than 0.05-0.10 and 0.10-0.20 m layers (Table 3), with the exception of both managements in Vitorino and CLS in Honório Serpa, reflecting the traffic of machinery and/or animal trampling used during the period prior to the evaluation, even using the minimum tillage and/or the vegetal residues remains on the surface of the soil (Table 1). In contrast, soil under NF, regardless of the farm, presented a lower BD and a higher $\mathrm{Ma}$ in the superficial layer in relation to the underlying layers (Table 3), reflecting the large residues contribution on its surface and the balance, in addition and loss of TOC, associated to the absence of animal trampling and/or machinery on its surface. This behavior converges with Albuquerque et al. (2001) and Aratani et al. (2009).

Among the agricultural management (CLS and SP), no significant differences were observed between the BD in the evaluated layers, except in the 0.00-0.05 $\mathrm{m}$ layer of the farm in Honório Serpa, where the BD under SP was larger $\left(1.23 \mathrm{Mg}^{-3}\right)$ in relation to soil under CLS $\left(1.13 \mathrm{Mg}^{-3}\right)$ (Table 3). This result evidences the possible animal trampling effect on soil surface layer, because in this farm, the area under SP supported an animal load 10.2 times higher $\left(3520 \mathrm{~kg} \mathrm{PV} \mathrm{ha}{ }^{-1}\right)$ in relation to an area under CLS $\left(345 \mathrm{~kg} \mathrm{PV} \mathrm{ha}^{-1}\right)$ at the $3^{\text {rd }}$ evaluated year (Table 1), since a high correlation was observed between stocking rate and soil density in a way that its bulk density increases, as the stocking rate increases (Figure 1). However, in the other farms, although the areas under SP received a higher animal load in relation to areas under CLS (1.6 to 7.5 times higher), this did not reflect the BD deterioration. This result converges with Flores et al. (2007), Balbinot Junior et al. (2009b), Spera et al. (2009) Silva et al. (2011) and Moreira et al. (2014), who attributed to the intense plants renewal of the root system, the reduction effect on the soil structure in pastures due to animal trampling.

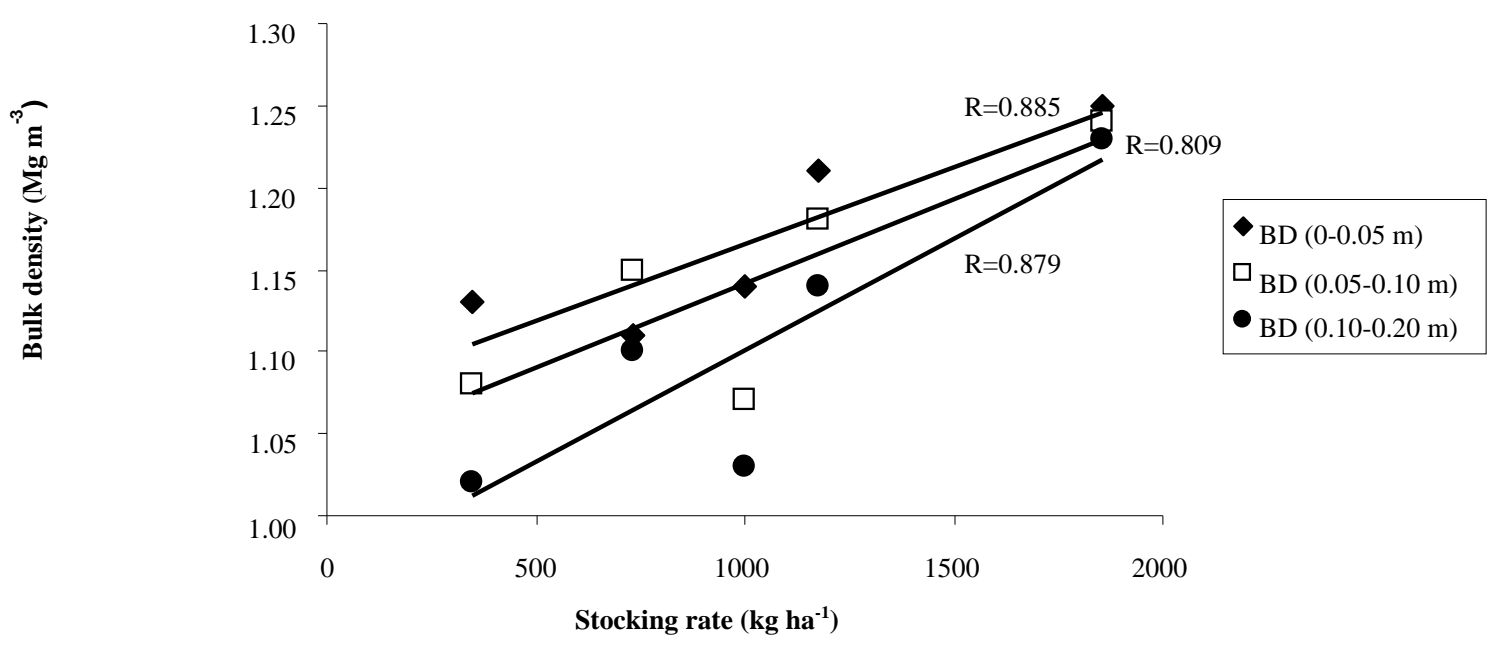


Figure 1. Correlation between stocking rate and soil bulk density under crop-livestock system (CLS), in three depths, and in five smallholders farm in the southwestern Paraná, Brazil

According to Reichert et al (2007), soil bulk density beyond $1.40 \mathrm{Mg} \mathrm{m}^{-3}$ in clayey soil is a very good indicator of compaction. Considering this value, it can be inferred that soil physical quality under CLS and SP in the different layers evaluated showed no deterioration, which is also evidenced by the BD values much lower than $1.40 \mathrm{Mg} \mathrm{m}^{-3}$. Moreover, the BD rest observed in the 0.00-0.20 m layer under CLS and SP presented, respectively, BD values of 9 to $21 \%$ and 11 to $19 \%$ below the critical limit (Table 4).

In addition to no restrictive BD values, soils under CLS and SP showed Ma equal to or greater than $10 \%$ in the different evaluated layer (Table 3), considered an adequate value for crop development (Girardelo et al., 2011; Baquero et al., 2012). However, values below 10\% in clayey soils generally do not compromise root development, due to the greater continuity of the porous system in these soils when compared to sandy soils (Håkansson and Lipiec, 2000; Reichert et al., 2009). Therefore, the lowest Ma value in the 0.00-0.05 m layer under SP $(8 \%)$ in relation to CLS (17\%), on the Honório Serpa farm, does not necessarily imply an inadequate physical condition (Table 3). The difference in Ma between these treatments may be a reflection on the stocking rate under SP area (7.5 times greater than CLS area) or it can be a reflex of management adopted under CLS at the $3^{\text {rd }}$ year, due to the soil tillage for bean crop in the summer, followed by minimum tillage for oat and ryegrass crop (Table 1). On the other hand, in others farms, the soil under CLS and SP did not differ and presented a Ma equal or higher than 10\%. This result agrees with Spera et al. (2009) and Silva et al. (2011), who also observed Ma equal or greater than $10 \%$ at the 0 to $0.20 \mathrm{~m}$ depth in clayey soil under crop-livestock and perennial pasture.

Table 4. Mean values of the bulk density, restrictive to root growth (BDRest) and bulk density (BD), crop-livestock system (CLS) and summer pasture (SP) in the 0.00-0.20 m layer, on five smallholder's farms in the southwest of Paraná, Brazil

\begin{tabular}{lccc}
\hline Locality & BDRest* $^{*}$ & BD CLS & BD SP \\
\hline Honório Serpa & 1.37 & $1.08(-21 \%)^{* *}$ & $1.17(-15 \%)^{* *}$ \\
Saudade do Iguaçu & 1.40 & $1.18(-16 \%)^{* *}$ & $1.14(-19 \%)^{* *}$ \\
Vitorino & 1.42 & $1.12(-21 \%)^{* *}$ & $1.15(-19 \%)^{* *}$ \\
Pato Branco & 1.31 & $1.17(-11 \%)^{* *}$ & $1.14(-13 \%)^{* *}$ \\
Ampere & 1.37 & $1.24(-9 \%)^{* *}$ & $1.22(-11 \%)^{* *}$ \\
\hline
\end{tabular}

$*$ BDRest $=1.86-0.00071$ clay (Reichert et al., 2009); **: differences between the BD of the areas under CLS and SP in relation to BDRest.

In relation to the Mi volume, treatments under CLS and SP did not differ significantly and presented, on average, values higher than $40 \%$, independently on the evaluated layer (Table 3), corroborating with Kunz et al. (2013) and Bortolini et al. (2016), who also did not observe significant changes in the porous system on clayey soil under CLS, with or without grazing for 3 and 10 years, respectively. On the other hand, the Mi under non-anthropogenic 
environment (NF) showed an average value of $35 \%$ in the $0.00-0.05 \mathrm{~m}$ layer to $36 \%$ in the $0.05-0.10 \mathrm{~m}$ layer, and $36 \%$ in the $0.10-0.20 \mathrm{~m}$ layer, practically the same proportion of $\mathrm{Ma}$ that presented in the respective layers evaluated (Table 3 ).

It is observed that there was a high correlation between the density of the soil and the different types of porosities analyzed in different locations and depths, and with the increase in soil density, there was a decrease in macroporosity and total porosity, and an increase in microporosity (Figure 2). This effect was expected considering that the increase in density has a main effect on the decrease in macroporosity and total porosity, where that part of the macropores starts to form micropores, which explains the fact that with the increase in density, there will be an increase in micropores.

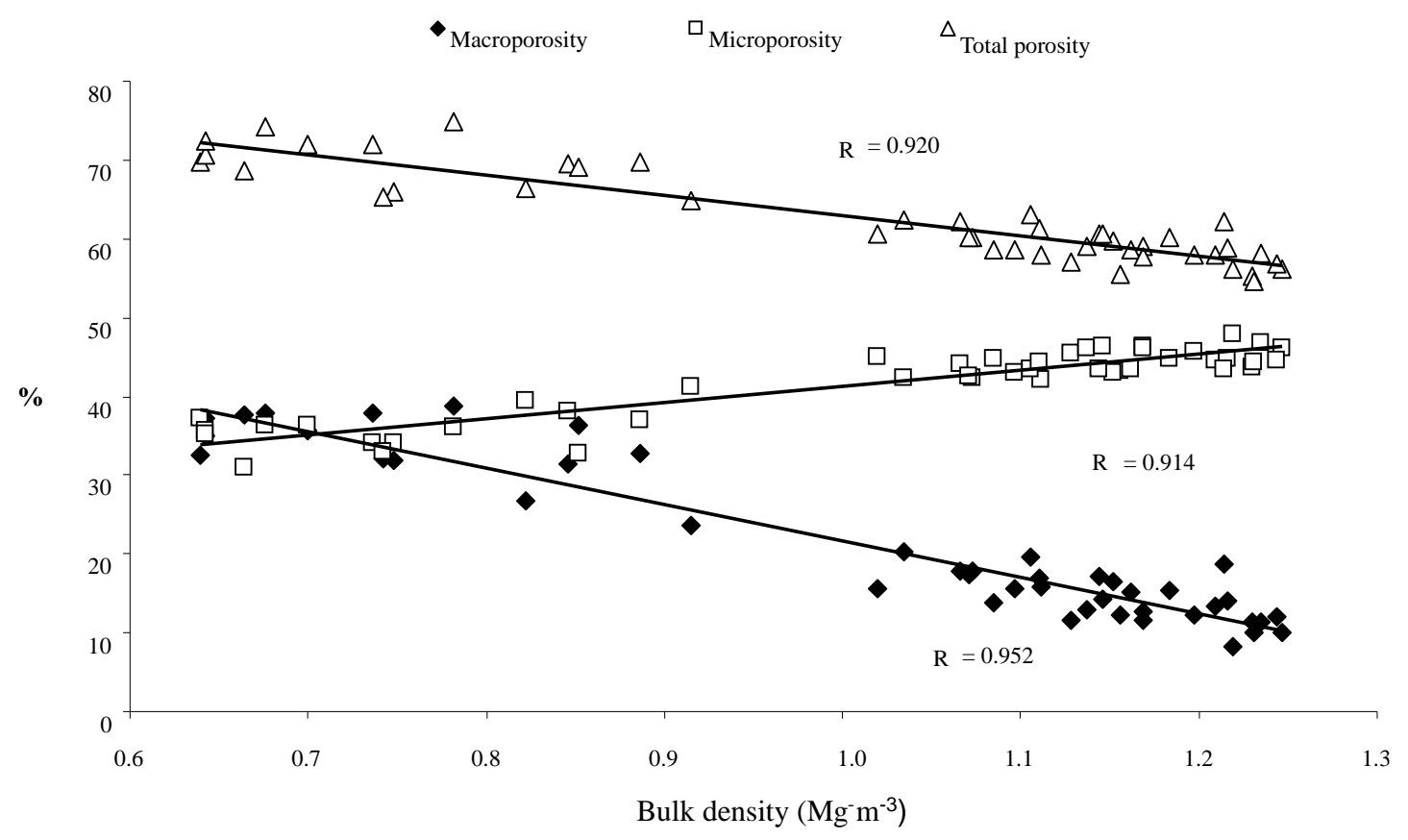

Figure 2. Correlation of bulk density with total porosity, microporosity and macroporosity of soils under crop-livestock system (CLS), summer pasture (SP) and native vegetation (NF) in five agricultural smallholders' farms. Data obtained at 0-0.05 m, 0.05-0.10 m and 0.10-0.20 $\mathrm{m}$ soil depths in the southwestern Paraná, Brazil

The results showed so far, allow us to infer that the conservation management adoption, such as the vegetal residues input or less traffic/trampling on the soil surface or soil tillage suppression, promote in the short and medium term a different physical condition from the natural soil. However, this new physical condition does not necessarily imply degradation of the environment, because when properly managed, soils can carry out both productive and ecological functions, according to results discussed previously. In this sense, an important factor that contributes to the minimization of the compressive effects of grazing and/or machine traffic in CLS, is the amount of forage mass available (Moreira et al., 2014), and the root biomass, which can increase the soil recovery capacity after eventual compaction 
(Balbinot et al., 2009b).

About the soil aggregation, in the general average of the farms, higher WMD values were observed in the soils under LCS and SP in relation to NF, mainly at $0.10 \mathrm{~m}$ depth (Table 1). This behavior can be due to the area's use history, mainly to the traffic and/or animals trampling which may form larger aggregates, as already observed by Salton et al. (2008), Bergamin et al. (2010) and Conte et al. (2011). However, these aggregates generally present a smaller pore volume, with a higher proportion of fine pores as a result of the decrease of larger pores (Baumgartl and Horn, 1991; Horn et al., 1995; Bertol et al., 2004). This behavior (greater proportion of $\mathrm{Mi}$ in relation to $\mathrm{Ma}$ ) was observed in soils under CLS and SP in relation to NF soil (practically the same Ma and Mi rate), as previously discussed (Table 3). On the other hand, the root biomass of grasses used in soil under SP and CLS, mainly in winter season, can have also influenced the highest aggregates stability in these areas, and consequently contributed to the higher MWD values, as well as in the adequate BD and Ma values in the different soil layers (Table 3). The positive action of grasses, which culminated in similar MWD, BD and Ma values among areas under conservation management were also observed by Lanzanova et al. (2007), Aratani et al. (2009), Spera et al. (2009), Batista et al. (2013) and Borges et al. (2016).

Thus, there is no differences to the MWD values when the areas under CLS and SP are compared on the different evaluated layers, and in most of the farms (Table 3). This result may be due to the similar TOC values observed in the areas under agricultural management (Table 3) associated to the high clay content observed in the different soil types (Table 1), and by the developed root system of the grasses used in the areas along the years. All these possibilities agree with results obtained by Six et al. (2004), Wendling et al. (2005), Ferreira et al. (2007), Salton et al. (2008), Souza et al. (2009), Ramos et al. (2013) and Bortolini et al. (2016)

Otherwise, in Pato Branco and Honório Serpa, the MWD under CLS was significantly lower in relation to the SP respectively in the 0.00-0.05 and 0.10-0.20 m layer (Table 3). In Pato Branco, the lowest MWD under CLS in the superficial layer is possibly due to the lower aerial and root biomass of the soybean when compared to the millet-sorghum consortium used in the area under SP in summer time (Table 1). According to Carpenedo and Mielniczuk (1990), the soil under grasses presented more aggregate stability than soil under leguminous, due to the mechanical action of grass roots, associated to high root biomass. In Honório Serpa, there is more MWD under SP in the 0.10-0.20 m layer probably due to the reconsolidation of the particles caused by the no-tillage, since the 2007/2008 winter harvest (Table 1). To Wendling et al. (2005) several agents create changes in soil structure, which may be transient or prolonged for years. Hence, it is recommended, in next studies about soil physical condition under CLS and SP, to evaluate the morphological patterns of the aggregates (if they are physiogenic, biogenic or intermediate) as shown in Batista et al. (2013). Thus, the next research could explain better the physical and biological influence on the soil aggregate genesis.

In general, considering $\mathrm{BD}, \mathrm{Ma}$ and $\mathrm{MWD}$ in all layers, it was verified that the soil 
management under CLS did not imply in physical degradation in the studied farms, even when they adopted some practices on soil tillage (Table 1). Possibly, the soils cover maintenance throughout the years, associated to ryegrass + oats crop in the winter along the evaluated period, interfered positively in the result aforementioned.

This study conclusions are: 1) the areas under CLS altered physical attributes, (higher BD and $\mathrm{Mi}$ and lower $\mathrm{Ma}$ ) in relation to the native florest area as a consequence of the land use history. However, the conservationist management adopted, with soil cover maintenance along the years after the implementation of the CLS, with minimum tillage and using grasses with aggressive roots along the winter period, did not culminate in limitations of soil functions; 2) the aggregation dynamics in the areas under CLS needs to be better investigated to determine the preponderant influence (biological or physical) on soil structure formation.

\section{Acknowledgments}

To the Institute of Development Rural of Paraná - IAPAR-EMATER, and the family farms collaborators of the Reference Networks for Family Agriculture Program, for the research support.

To CNPq and FA for the support to the researcher through granting scholarships. This study was financed in part by the Coordenação de Aperfeiçoamento de Pessoal de Nível Superior Brasil (CAPES) - Finance Code 001.

\section{References}

Assmann, A.L., Pin, E.A. (2008). Manejo de biomassa. In: Assmann, A.L., Soares, A.B., Assmann, T.S. (Orgs.). Integração lavoura-pecuária para a agricultura familiar. (p. 11-14) Londrina: IAPAR

Albuquerque, J. A., Sangoi, L., \& Ender, M. (2001). Efeitos da integração lavoura-pecuária nas propriedades físicas do solo e características da cultura do milho. Revista Brasileira de Ciência do Solo, 25(3), 717-723. https://doi.org/10.1590/s0100-06832001000300021

Anghinoni, I., Moraes, A., Carvalho, P. C. F., Souza, E. D., Conte, O., \& Lang, C. R. (2011). Benefícios da integração lavoura-pecuária sobre a fertilidade do solo em sistema plantio direto. In A. F. da FONSECA, E. F. CAIRES, \& G. BARTH (Orgs.), Fertilidade do solo e nutrição de plantas no sistema plantio direto. (p. 1-31). Ponta Grossa: AEACG/Inpag.

Aratani, R. G., Freddi, O. S., Centurion, J. F., \& Andrioli, I. (2009). Qualidade física de um latossolo vermelho acriférrico sob diferentes sistemas de uso e manejo. Revista Brasileira de Ciência do Solo, 33(3), 677-687. https://doi.org/10.1590/S0100-06832009000300020

Balbinot Junior, A. A., Moraes, A. de, Veiga, M., Pelissari, A., \& Dieckow, J. (2009a). Integração lavoura-pecuária: intensificação de uso de áreas agrícolas. Ciência Rural, 39(6), 1925-1933. https://doi.org/10.1590/S0103-84782009005000107

Balbinot Junior, A. A., Moraes, A., Pelissari, A., Veiga, M., Dieckow, J., \& Nunes Nesi, C. (2009b). Propriedades físicas em Cambissolo Háplico manejado sob o sistema integração lavoura-pecuária 1 Physical properties of a Haplic Cambissol subjected to integrated 
crop-livestock system. Revista de Ciências Agroveterinárias. Lages, 8(1), 25-34. https://revistas.udesc.br/index.php/agroveterinaria/article/view/5310

Batista, I., Correia, M. E. F., Pereira, M. G., Bieluczyk, W., Schiavo, J. A., \& Mello, N. A. (2013). Caracterização dos agregados em solos sob cultivo no cerrado, MS. Semina: Ciências Agrárias, 34(4). https://doi.org/10.5433/1679-0359.2013v34n4p1535

Baumgartl, T., \& Horn, R. (1991). Effect of aggregate stability on soil compaction. Soil and Tillage Research, 19(2-3), 203-213. https://doi.org/10.1016/0167-1987(91)90088-F

Baquero, J. E., Ralisch, R., Medina, C. C., Filho, J. T., \& Guimarães, M. F. (2012). Propriedades físicas de solo e crescimento radicular de cana-de-açúcar em um Latossolo Vermelho. Revista Brasileira de Ciencia do Solo, 36(1), 63-70. https://doi.org/10.1590/S0100-06832012000100007

Bergamin, A. C., Vitorino, A. C. T., Franchini, J. C., Souza, C. M. A., \& Souza, F. R. (2010). Induced compaction of a Rhodic Acrustox as related to maize root growth. Revista Brasileira de Ciencia do Solo, 34(3), 681-691. https://doi.org/10.1590/s0100-06832010000300009

Bertol, I., Albuquerque, J. A., Leite, D., Amaral, A. J., \& Zoldan Junior, W. A. (2004). Physical soil properties of conventional tillage and no-tillage, in crop rotation and succession, compared with natural pasture. Revista Brasileira de Ciencia do Solo, 28(1), 155-163. https://doi.org/10.1590/s0100-06832004000100015

Borges, W. L. B., Souza, I. M. D., Sá, M. E., \& Alves, M. C. (2016). Estabilidade de agregados em Latossolos sob plantas de cobertura em rotação com soja e milho. Revista Brasileira de Ciencias Agrarias, 11(3), 156-162. https://doi.org/10.5039/agraria.v11i3a5378

Bortolini, D., Albuquerque, J. A., Rech, C., Mafra, Á. L., Ribeiro Filho, H. M. N., \& Pértile, P. (2016). Propriedades físicas do solo em sistema de integração lavoura-pecuária em Cambissolo Húmico. Revista de Ciências Agroveterinárias, 15(1), 60-67. https://doi.org/10.5965/223811711512016060

Braida, J. A., \& Reichert, J. M. (2014). Matéria Orgânica e comportamento mecânico para fins de manejo de solo. In Luiz Fernando Carvalho Leite, G. A. Maciel, \& A. S. F. Araújo (Orgs.), Agricultura Conservacionista no Brasil (p. 309-339). Brasília, DF: Embrapa.

Campos, B. H. C., Amado, T. J. C., Bayer, C., Nicoloso, R. S., \& Fiorin, J. E. (2011). Carbon stock and its compartments in a subtropical Oxisol under long-term tillage and crop rotation systems. Revista Brasileira de Ciencia do Solo, 35(3), 805-817. https://doi.org/10.1590/s0100-06832011000300016

Carpenedo, V., \& Mielniczuk, J. (1990). Estado de agregação e qualidade de agregados de Latossolos Roxos submetidos a diferentes sistemas de manejo. Revista Brasileira de Ciência do Solo, 14(1), 99-105.

Carvalho, J. S., Kunde, R. J., Stöcker, C. M., Lima, A. C. R., \& Silva, J. L. S. (2016). Evolução de atributos físicos, químicos e biológicos em solo hidromórfico sob sistemas de integração lavoura-pecuária no bioma Pampa. Pesquisa Agropecuaria Brasileira, 51(9), 
1131-1139. https://doi.org/10.1590/S0100-204X2016000900012

Conte, O., Wesp, C. L., Anghinoni, I., Carvalho, P. C. F., Levien, R., \& Nabinger, C. (2011). Densidade, agregação e frações de carbono de um argissolo sob pastagem natural submetida a níveis de ofertas de forragem por longo tempo. Revista Brasileira de Ciencia do Solo, 35(2), 579-587. https://doi.org/10.1590/S0100-06832011000200027

Cordeiro, L. A. M., Vilela, L., Marchão, R. L., Kluthcouski, J., \& Júnior, G. B. M. (2017). Integração lavoura-pecuária e integração lavoura-pecuária-floresta: estratégias para intensificação sustentável do uso do solo. In Cadernos de Ciência \& Tecnologia (Vol. 32, Issue 1/2). https://doi.org/http://dx.doi.org/10.35977/0104-1096.cct2015.v32.23294

Donagema, G. K., Campos, D. V. B., Calderano, S. B., Teixeira, W. G., \& Viana, J. H. M. (2011). Manual de métodos de análise de solo. In Embrapa Solos. Rio de Janeiro: Embrapa Solos.

Ferreira, E. V. O., Anghinoni, I., Carvalho, P. C. F., Costa, S. E. V. G. A., \& Cao, E. G. (2009). Soil potassium content in an integrated crop-livestock system under no-tillage with different grazing intensities. Revista Brasileira de Ciencia do Solo, 33(6), 1675-1684. https://doi.org/10.1590/s0100-06832009000600016

Ferreira, F. P., Azevedo, A. C., Dalmolin, R. S. D., \& Girelli, D. (2007). Organic carbon, iron oxides and aggregate distribution in two basaltic soils from Rio Grande do Sul state - Brasil. Ciencia Rural, 37(2), 381-388. https://doi.org/10.1590/s0103-84782007000200013

Flores, J. P. C., Anghinoni, I., Cassol, L. C., Carvalho, P. C. F, Dal Belo Leite, J. G., \& Fraga, T. I. (2007). Soil physical attributes and soybean yield in an integrated livestock-crop system with different pasture heights in no-tillage. Revista Brasileira de Ciencia do Solo, 31(4), 771-780. https://doi.org/10.1590/s0100-06832007000400017

Girardello, V. C., Amado, T. J. C., Nicoloso, R. S., Hörbe, T. A. N., Ferreira, A. O., Tabaldi, F. M., \& Lanzanova, M. E. (2011). Alterações nos atributos físicos de um latossolo vermelho sob plantio direto induzidas por diferentes tipos de escarificadores e o rendimento da soja. Revista Brasileira de Ciencia do Solo, 35(6), 2115-2126. https://doi.org/10.1590/S0100-06832011000600026

Håkansson, I., \& Lipiec, J. (2000). A review of the usefulness of relative bulk density values in studies of soil structure and compaction. Soil and Tillage Research, 53, 71-85. https://doi.org/10.1016/S0167-1987(99)00095-1

Horn, R., Domzzał, H., Słowińska-Jurkiewicz, A., \& van Ouwerkerk, C. (1995). Soil compaction processes and their effects on the structure of arable soils and the environment. Soil and Tillage Research, 35(1-2), 23-36. https://doi.org/10.1016/0167-1987(95)00479-C

IBGE - Instituto Brasileiro de Geografia e Estatística (2006). Censo agropecuário 2006. http://biblioteca.ibge.gov.br/visualizacao/periodicos/50/agro_2006_agricultura_familiar.pdf

Kunz, M., Gonçalves, A. D. M. A., Reichert, J. M., Guimarães, R. M. L., Reinert, D. J., \& Rodrigues, M. F. (2013). Compactação do solo na integração soja-pecuária de leite em 
Latossolo argiloso com semeadura direta e escarificação. Revista Brasileira de Ciencia do Solo, 37(6), 1699-1708. https://doi.org/10.1590/S0100-06832013000600026

Lanzanova, M. E., Nicoloso, R. S., Lovato, T., Eltz, F. L. F., Amado, T. J. C., \& Reinert, D. J. (2007). Soil physical attributes in integrated cattle raising-crop production system under no-tillage. Revista Brasileira de Ciencia do Solo, 31(5), 1131-1140. https://doi.org/10.1590/s0100-06832007000500028

Moreira, W. H., Tormena, C. A., Junior, E. B., Petean, L. P., \& Alves, S. J. (2014). Influência da altura de pastejo de azevém e aveia em atributos físicos de um latossolo vermelho distroférrico, após sete anos sob integração lavoura-pecuária. Revista Brasileira de Ciencia do Solo, 38(4), 1315-1326. https://doi.org/10.1590/S0100-06832014000400027

Perin, E., Vieira, J. A. N., Lovato, L. F., Machado, M. L. S., \& Bertuol, O. (2001). Sistemas de Referências para a Agricultura Familiar na Região Sudoeste do Paraná. Londrina-PR, IAPAR/EMATER

Ramos, F. T., Ramos, D. T., Azevedo, E. C., Maia, J. C. S., \& Roque, M. W. (2013). Modificações Físicas em Um Latossolo Vermelho-Amarelo Distrófico no Cerrado sob Diferentes Sistemas de Manejo. Global Science and Technology, 6(1), 12-25. https://doi.org/10.14688/1984-3801.v06n01a02

Reichert, J.M., Suzuki, L. E. A. S., \& Reinert, D. J. (2007). Compactação do solo em sistemas agropecuários e florestais: identificação, efeitos, limites críticos e mitigação. In C. A. Cerreta, L. S. Silva, \& J. M. Reichert (Orgs.), Tópicos em Ciência do Solo (p. 49-134). Sociedade Brasileira de Ciência do Solo

Reichert, J. M., Suzuki, L. E. A. S., Reinert, D. J., Horn, R., \& Håkansson, I. (2009). Reference bulk density and critical degree-of-compactness for no-till crop production in subtropical highly weathered soils. Soil and Tillage Research, 102(2), 242-254. https://doi.org/10.1016/j.still.2008.07.002

Salton, J. C., Mielniczuk, J., Bayer, C., Boeni, M., Conceição, P. C., Fabrício, A. C., Broch, D. L. (2008). Soil aggregation and aggregate stability under crop-pasture systems in Mato Grosso do Sul state, Brazil. Revista Brasileira de Ciencia do Solo, 32(1), 11-21. https://doi.org/10.1590/s0100-06832008000100002

SEAB - Secretaria da Agricultura e do Abastecimento do Paraná (2010). Paraná 12 meses. http://www.simep.seab.pr.gov.br/pr12meses/index.html

Silva, R. F., Guimarães, M.F., Aquino, A. M., \& Mercante, F. M. (2011). Análise conjunta de atributos físicos e biológicos do solo sob sistema de integração lavoura-pecuária. Pesquisa Agropecuaria Brasileira, 46(10),

1277-1283. https://doi.org/10.1590/S0100-204X2011001000023

Six, J., Bossuyt, H., Degryze, S., \& Denef, K. (2004). A history of research on the link between (micro)aggregates, soil biota, and soil organic matter dynamics. Soil and Tillage Research, 79, 7-31. https://doi.org/10.1016/j.still.2004.03.008 


\section{Macrothink}

Souza, E. D., Costa, S. E. V. G. A., Anghinoni, I., Carvalho, P. C. F., Andrigueti, M., \& Cao, E. (2009). Soil organic carbon and nitrogen stocks in an untilled crop-livestock system system under different grazing intensities. Revista Brasileira de Ciencia do Solo, 33(6), 1829-1836. https://doi.org/10.1590/s0100-06832009000600031

Spera, S. T., Santos, H. P., Fontaneli, R. S., \& Tomm, G. O. (2009). Livestock-crop integration effects on physical attributes of a soil under no-till. Revista Brasileira de Ciencia do Solo, 33(1), 129-136. https://doi.org/10.1590/s0100-06832009000100014

Tedesco, M. J., Gianello, C., Bissani, C. A., Bohnen, H., \& Volkweiss, S. J. (1995). Análises de solo, plantas e outros materiais (2.ed. rev.). Porto Alegre: UFRGS.

Wendling, B., Jucksch, I., Mendonça, E. S., \& Neves, J. C. L. (2005). Organic carbon and aggregate stability of a Red Latossol under different managements. Pesquisa Agropecuaria Brasileira, 40(5), 487-494. https://doi.org/10.1590/s0100-204x2005000500010

\section{Copyright Disclaimer}

Copyright for this article is retained by the author(s), with first publication rights granted to the journal.

This is an open-access article distributed under the terms and conditions of the Creative Commons Attribution license (http://creativecommons.org/licenses/by/4.0/). 